\title{
Our Unfinished Debate about Market Socialism ${ }^{1}$
}

\author{
David Miller \\ Nuffield College, Oxford
}

\section{Introduction}

This article presents and reflects upon a debate about socialism between Jerry Cohen and myself that originally took place in 1989, but remained, as I shall try to show, unfinished in certain respects at the time of his sudden and tragic death in 2009. Few readers will need reminding of the significance of the former date for the historical trajectory of socialism: the Soviet Union was undergoing massive reform, Communist regimes in Eastern Europe were on the point of collapse, and the Berlin Wall was shortly to fall. Far lower down on the register of historical significance, the British Labour Party, after three successive electoral defeats, was undergoing the long process of ideological realignment that would culminate in the following decade in the abandonment of Clause Four of its Constitution, ${ }^{2}$ and the apotheosis of Tony Blair and the so-called Third Way (between capitalism and socialism, allegedly). It seemed an apposite moment, therefore, to consider the future of socialism, and to ask which of the values and commitments that had inspired the various strands within the socialist movement over the last century and a half still retained their relevance.

The specific focus of our exchange was market socialism, a position whose rationale I had recently set out and defended in Market, State and Community and in a shorter

\footnotetext{
${ }^{1}$ This is a revised version of a paper written for the workshop on 'G.A. Cohen and Socialism', Centre for Advanced Studies 'Justitia Amplificata', Goethe University of Frankfurt, April 8-9, 2011. I should like to thank the participants in that meeting for their suggestions, and especially Zosia Stemplowska for her help in preparing the paper for publication.

${ }^{2}$ For those not well versed in Labour Party theology, the original Clause Four, dating back to 1918, committed the party 'To secure for the workers by hand or by brain the full fruits of their industry and the most equitable distribution thereof that may be possible upon the basis of the common ownership of the means of production, distribution and exchange, and the best obtainable system of popular administration and control of each industry or service.'
} 
essay 'A Vision of Market Socialism' that summarised the argument of the book. ${ }^{3}$ Cohen's initial reply to these materials was presented in a paper 'David Miller on Market Socialism and Distributive Justice’ that has remained unpublished, although some of the ideas it contains found their way in shortened form into his essay 'The Future of a Disillusion', first published in the New Left Review and then later reprinted as the last chapter of Self-Ownership, Freedom, and Equality. ${ }^{4}$ This later essay conveys Cohen's general response to the collapse of Soviet Communism, seen through the eyes of someone whose early political formation had been in the bosom of the Canadian Communist Party. The earlier paper, however, contains a fuller philosophical critique of market socialist ideas, and is of considerable independent interest for the light it throws on Cohen's thinking on matters such as the role of desert in distributive justice, and the nature of market motivation. It was intended by Cohen to be available in the public domain, since he invited readers of 'The Future of a Disillusion' to apply to him for a copy. ${ }^{5}$

Although Cohen was at this stage in his life in the process of abandoning some of the tenets of orthodox Marxism - particularly some important aspects of the Marxist theory of history - his understanding of socialism always retained much of the Marxist vision of the higher stage of communism. It was the idea of a society that had transcended not only capitalism but also market relations more generally, a society in which each would find fulfilment by setting aside his own interests, at least partially, in order to contribute productively to the common good. From this perspective, market socialism could be seen as an improvement on capitalism only insofar as it reduced capitalism's exploitative nature along one dimension: it removed exploitation

${ }^{3}$ D. Miller, Market, State, and Community: Theoretical Foundations of Market Socialism (Oxford: Clarendon Press, 1989); D. Miller, 'A Vision of Market Socialism', Dissent, Summer 1991, 406-14.

${ }^{4}$ G. A. Cohen, 'The Future of A Disillusion', New Left Review, 190 (1991), 5-20; G.A. Cohen, Self-Ownership, Freedom, and Equality (Cambridge: Cambridge University Press, 1995), ch. 11.

${ }^{5}$ See Cohen, Self-Ownership, Freedom, and Equality, p. 257. The copy of the paper that I have is richly annotated by hand, suggesting that Cohen was polishing it for possible publication (and incidentally providing evidence of the pride Cohen took in felicitous verbal expression). I reproduce various passages in the course of this article for the benefit of those without direct access to it. 
that stemmed from the ownership of capital, but left in place what Cohen called 'socialist exploitation', most notably the exploitation of the less talented by the more talented by virtue of the income inequalities it permitted. Nevertheless he was willing to concede that market socialism was 'the agendum of our age', the kind of system we could aspire to create in the immediate aftermath of capitalism. ${ }^{6}$ What he was not willing to concede was that it had principled foundations, other than its abovementioned claim to have removed the specifically capitalist form of exploitation.

In the years following 1989, Cohen said little more about his own understanding of socialism, ${ }^{7}$ apart from for a rather fierce exchange with Bernard Williams in the 1990s, prompted by Williams' role in providing the philosophical basis for the Commission on Social Justice, set up by the new Labour leader, John Smith, in 1992. ${ }^{8}$ Recording his 'consternation and, sometimes, shock' at the pamphlets produced in advance of the Commission's final report, Cohen argued that the two distinctively socialist principles were equality and community, and more specifically that 'the market, any market, contradicts the principles which not only Marx but his socialist predecessors proclaimed for the good society, the principle embodied in the slogan "from each according to his abilities, to each according to his needs", 9

It was therefore unexpected that, shortly before his death Cohen should have chosen to republish in book form a short essay that he had written in defence of socialism. ${ }^{10}$

${ }^{6}$ G.A. Cohen, 'David Miller on Market Socialism and Distributive Justice’, p. 1. Future citations of this paper will be given simply as page numbers.

${ }^{7}$ He defended the Labour Party’s original Clause Four against Tony Blair's replacement text in a short pamphlet Is Socialism Inseparable from Common Ownership? (European Labour Forum: Nottingham, 1995).

${ }^{8}$ Williams was the inspiration behind two of the Commission's preliminary publications: The Justice Gap (London: IPPR, 1993) and Social Justice in a Changing World (London: IPPR, 1993). The ideas in these short pamphlets were condensed to appear in the final report Social Justice: Strategies for National Renewal (London: Vintage, 1994). His response to Cohen's critique can be found in B. Williams, 'Forward to Basics' in J. Franklin (ed.), Equality (London: IPPR, 1997).

${ }^{9}$ G. A. Cohen, 'Back to Socialist Basics' in J. Franklin (ed.), Equality (London: IPPR, 1997), p. 37. 
His motives for doing so are unclear. Apart from the example of the camping trip that introduces the essay, the defence of socialism that is offered here, grounded in the ideals of equality and community, is not different from that presented in his earlier work. The verdict on market socialism remains unchanged: it is conceded that markets are an efficient way of organizing production, and that market socialism 'scores far better' by standards of distributive justice than capitalism does; so it remains 'an eminently worthwhile project' for the here and now. From a socialist point of view, however:

Market socialism nevertheless remains deficient...because, by socialist standards, there is injustice in a system that confers high rewards on people who happen to be unusually talented and who form highly productive cooperatives. Market socialism is also a deficient socialism because the market exchange that lies at its heart tends against the value of community. ${ }^{11}$

Given this verdict, which condemns market socialism on the same grounds as those Cohen had advanced in 1989, why do I describe our debate as unfinished? Had we not simply reached a philosophical impasse in which rival versions of socialism were being defended on the basis of different underlying value-premises? In my view, the earlier debate had been coloured by the political circumstances in which it occurred. Cohen at that time was inclined to see market socialism as merely an unprincipled retreat from socialism proper, driven by the perception that nothing better was presently feasible. He speaks of a ‘Gadarene rush' on the part of a number of socialist intellectuals away from the disaster of comprehensive central planning (p. 4). ${ }^{12} \mathrm{He}$ also described it as an example of adaptive preference formation: the fox who cannot reach the grapes convinces himself that they must be sour. Now according to Cohen:

${ }^{10}$ G. A. Cohen, Why not Socialism? (Princeton, N.J.: Princeton University Press, 2009).

${ }^{11}$ Cohen, Why not Socialism?, p. 74

${ }^{12}$ My own attempt to defend market socialism had begun with 'Socialism and the Market', Political Theory, 5 (1977), 473-90, written well before there was any evidence that the Soviet Union was about to collapse, so if there was a Gadarene rush, at least I was a slow pig. 
The sour grapes response is not always unproductive. If Harry will not marry you, and Johnny, whom you do love, but not as much, will, then it may be seemly and sensible for you to develop a preference for Johnny.....But the sour grapes response can be destructive. It is bad when, because you have made it, you lose standards of value and achievement which should be retained to sustain criticism of what for the time being has to be and to improve it when it is possible to improve it. Sour grapes deprives you of the ideals you need to keep the faith for a future which may offer ampler possibilities. If you forget about the goodness of what is now impossible, you may fail to seize it when it becomes available and you will do nothing to try to make it possible....If the fox succeeds in convincing himself that the grapes are sour, he will not pick them when, finally, they are so ripe and heavy that they will bend the branch and come within his reach. (p. 5)

Because he saw market socialism in this way, and also perhaps because as the last sentence cited above suggests, he kept (in 1989) a little of the Marxist belief that history must move in such a way that the grapes do finally develop to the point where they are ripe, he was unwilling to concede that there might be principled reasons for favouring market socialism, even in circumstances where his favoured communitarian alternative was available. He was also unwilling to allow that, looking back at the history of socialist ideas, market socialism might claim to have roots in that tradition that were as deep as those of the communitarian version. Twenty years later, it had become clear to everyone, including Cohen, that history was no longer (if it ever had been) moving inexorably in the direction of socialism, which appeared to create the space for an explicitly normative assessment of different versions of socialism without anyone being accused of swine- or fox-like behaviour. In the light, also, of the more explicit value-pluralism of his later writings, it seemed possible that Cohen might be persuaded that market socialism represented an attractive way of reconciling values all of which socialists should endorse; perhaps it would even be possible to convince him that Marx would have taken a more nuanced stance towards it than the 
one that Cohen took himself. ${ }^{13}$ Since such hopes for a continuing debate remain tragically unfulfilled, I attempt in this article to reconstruct as fairly as I can, drawing especially on Cohen's unpublished text, the arguments that led us to our opposing conclusions.

\section{Some relevant background}

It may be helpful at this point to frame the original debate by sketching in how the idea of market socialism had developed in the 1980s, in Britain especially. It was fed by two main streams. From one direction, there was debate among economists about the Soviet system, and how its glaring inefficiencies might be rectified by introducing market-led reforms. A version of market socialism had long existed in Yugoslavia, and other countries within the Soviet empire, especially Hungary, had begun to experiment by allowing small businesses to operate on a market basis. An influential text here was Alec Nove's The Economics of Feasible Socialism, published in 1983, which reviewed critically the performance of Soviet-style communism and proposed a range of reforms that might be introduced in response to its manifest failings. ${ }^{14}$ From the other direction, intellectuals sympathetic to the Labour Party were becoming more critical of the version of social democracy that the party had been promoting in the period from1945 up until 1979, when it succumbed electorally to the neo-liberalism championed by Margaret Thatcher. It was seen as being too statist in character - it gave people what the government and the civil service thought was good for them, rather than what they might have chosen for themselves if allowed to do so. It was also seen as having failed in its declared intention to reduce social inequalities. Social democrats had assumed that the tax-and-welfare system would combat the inequalities generated by capitalism, first by making post-tax incomes more equal, and second by providing, through the welfare state, essential goods and services to everyone free of charge. The hoped-for reduction in inequality proved, however, to be elusive: periods of Labour government were followed by post-mortems in which it was shown that

\footnotetext{
${ }^{13}$ I had argued this case in 'Marx, Communism and Markets', Political Theory, 15 (1987), 182-204, later incorporated into Market, State and Community as ch. 8.

${ }^{14}$ A Nove, The Economics of Feasible Socialism (London: Allen and Unwin, 1983).
} 
inequality had not, in fact, significantly declined over the period in question. ${ }^{15}$ Moreover the claim that publicly-funded welfare services led to equality of outcome was being challenged by studies that showed how the middle classes were able to benefit disproportionately from these services: an influential text here was Julian le Grand's The Strategy of Equality, published in $1982 .{ }^{16}$

The central claim made by market socialists, therefore, was that socialists should be willing to embrace the market economy, with tempered enthusiasm rather than reluctance, partly for reasons of efficiency, but also for reasons of personal freedom: it promised to liberate people, both as producers and as consumers, from the heavyhanded control of the state. But it was essential at the same time to look for new ways of framing the market - setting out the ground rules on whose basis the market should operate - so that it served socialist values, notably a much higher degree of material equality than was possible under capitalism. This did not mean abandoning the welfare state (though it did mean being willing to contemplate reforms that would give its clients greater freedom of choice). Market socialism was not a version of leftlibertarianism. It was a set of proposals for reforming the market economy that left it open for further discussion how large a proportion of the overall economy should be organized on a market basis, and how much should remain in the public and voluntary sectors.. The key point was that, rather than relying on redistribution via the state as the main vehicle for promoting equality, the market itself should be reconstituted so that with new rules of ownership the distribution of primary incomes would be significantly more equal than was inevitably the case under capitalism.

Different versions of market socialism were proposed. One maverick version that needs to be introduced at this point, since it influenced Cohen's thinking, is the scheme advanced by Joseph Carens in his book Equality, Moral Incentives and the

${ }^{15}$ Such as P. Townsend and N. Bosanquet (eds.), Labour and Inequality (London: Fabian Society, 1972) for the Labour governments of 1964-70, and N. Bosanquet and P. Townsend (eds.), Labour and Equality: a Fabian study of Labour in power, 197479 (London: Heinemann, 1980).

${ }^{16}$ J. Le Grand, The Strategy of Equality: Redistribution and the Social Services (London: Allen and Unwin, 1982). 
Market. ${ }^{17}$ Unlike other versions, Carens proposed to retain market institutions in their current form, but to do away with material incentives entirely. It would be possible, he argued, to achieve material equality without altering the institutional structure of conventional capitalism by first socialising children and adolescents into believing that they had a social obligation to maximise their pre-tax incomes, and then taxing such incomes at $100 \%$ and distributing the proceeds to everyone equally. So long as people continued to make their productive choices in the same way as they would have under capitalism - with ‘social duty satisfactions' replacing incomederived satisfactions when they were deciding e.g. about work/leisure trade-offs - the system would have similar efficiency credentials without the huge inequalities in post-tax incomes that disfigure capitalism.

Cohen lauded the Carens model, which he saw as responding adequately to the efficiency defects of centrally planned socialism, while conceding that it had problems. Carens himself had admitted, in a later paper referred to by Cohen, that imposing on individuals an obligation to maximise their pre-tax income might prove a barrier to individual self-realization, and so he proposed weakening the requirement so that it held only that people had a duty to make 'good use' of their productive talents rather than the best possible use. ${ }^{18}$ (This foreshadows Cohen's later concession that people should be regarded as having a 'personal prerogative' to resile from the full demands of distributive justice.) Surprisingly, perhaps, Cohen did not see Carens' model as being defective by virtue of its essentially competitive character, a topic I shall address below.

In contrast to Carens, more standard forms of market socialism assumed that market economies needed to make use of material incentives to motivate workers to choose their occupations and to produce efficiently, while aiming to alter the structure of capitalist enterprises more or less radically. One of the least radical proposals was John Roemer's A Future for Socialism - a book that post-dated the 1989 debate but

\footnotetext{
17 J. Carens, Equality, Moral Incentives and the Market: An Essay in Utopian Politico-Economic Theory (Chicago: University of Chicago Press, 1981).

${ }^{18}$ J. Carens, 'Rights and Duties in an Egalitarian Society', Political Theory, 14 (1986), 31-49.
} 
was referred to approvingly by Cohen in If You're an Egalitarian, How Come You're So Rich?, and again in Why Not Socialism ${ }^{19}$ Roemer had devised an ingenious scheme for socialising capital markets by giving each person, at birth, a set of vouchers of equal value that could then be used for (and only for) capital investment. The aim, therefore, was to eliminate inequality stemming from unequal initial holdings of capital - but not inequalities arising from talent differences in the labour market, or indeed inequalities arising from differential success in investing the vouchers. As in the case of Carens, ${ }^{20}$ the managerial structure of the capitalist firm is not challenged by this proposal, although its form of ownership clearly is, since firms would be run not by private entrepreneurs but by managers on the basis of capital borrowed via the voucher scheme. ${ }^{21}$

For mainstream market socialists, by contrast, such a challenge was fundamental. The preferred form of economic organization was the labour-managed firm, or workers' co-operative. There was much debate about how such co-operatives should be funded, given concerns about whether a market made up of such firms would be efficient. $^{22}$ The arguments for favouring co-operatives were, first, that it was desirable on democratic grounds for employees to control the firms that they worked

${ }^{19}$ J. Roemer, A Future for Socialism (London: Verso, 1974); G. A. Cohen, If You're an Egalitarian, How Come You're So Rich? (Cambridge, MA: Harvard University Press, 2000), p. 196; Cohen, Why not Socialism?, pp. 70-73.

${ }^{20}$ Carens briefly considers the objection that his proposal leaves untouched the inequalities of power and opportunity that prevail under capitalism, and argues that his scheme could, if necessary, be modified to respond to it - but he sees this issue as orthogonal to the distributive question that his proposal is intended to address. See Carens, Equality, Moral Incentives and the Market, pp. 180-3.

${ }^{21}$ Roemer recognizes that there are leftists who believe 'that what is principally valuable about socialism is its extension of democracy into economic life' but he defends 'managerial market socialism' on feasibility grounds and because of doubts about whether a labour-managed market economy would be efficient: see A Future for Socialism, ch. 14. In this light, Cohen's reiterated enthusiasm for the Roemer model remains somewhat puzzling.

${ }^{22}$ See the various papers included in S. Estrin and J. Le Grand (eds.), Market Socialism (Oxford: Clarendon Press, 1989). This collection gives a good overview of the state of discussion (in Britain) of market socialism at the point at which Cohen entered the fray. 
for; second, that although relations between co-operatives would often be competitive, relationships within them would, as the name suggests, be co-operative; and third, that although individuals with special skills and responsibilities could expect to be paid at a higher rate, income differentials within each firm would be much smaller than those within their capitalist counterparts.

In my essay, I had defended this third model of market socialism. I suggested that it might be assessed in terms of five underlying values that together were constitutive of the socialist tradition as a whole. These were 1) the conscious direction of social activities towards common purposes; 2) democracy (in a sense stronger than electoral democracy); 3) material equality; 4) freedom (in a sense stronger than narrow 'negative' freedom); and 5) community. ${ }^{23}$ Cohen and I readily agreed that the first of these values had to be set aside, at least in its undiluted form: the experience of central planning suggested that the aspiration to direct all social activities towards common ends was unachievable even if it was desirable. Cohen thought that the presence of this value in Marx might be explained as the legacy of the Hegelian idea of 'humanity rising to consciousness of and control over itself'. ${ }^{24}$ Thus the market could not be faulted on the grounds that it co-ordinated people's activity by an invisible hand mechanism rather than through conscious direction. As Cohen put it, the traditional socialist critique

'misguidedly.....criticized the market in its allocative function, and overplayed the significance of the unplanned nature of its co-ordination. It exaggerated the disaster that must come of that, because it failed to acknowledge how remarkably well the market organizes information signals, and how difficult it is to gather the information dispersed through the market in a planning centre. To that extent, Hayek is right.' (p. 25)

Cohen's own critique of market socialism therefore relied on an appeal to the remaining four values, and specifically to values 3 and 5 - equality and community.

\footnotetext{
${ }^{23}$ See Miller, ‘A Vision of Market Socialism’, p. 406.

${ }^{24}$ Cohen, Self-Ownership, Freedom, and Equality, p. 260.
} 
It is perhaps curious that he chose not to discuss value 2 - democracy - which I had presented as an important reason for preferring the co-operative version of market socialism to either the Carens or the Roemer version, both of which left the top-down command structure of the capitalist enterprise in place. It is also curious that he did not ask whether his powerful argument about proletarian unfreedom under capitalism would or would not apply to market socialism. For Cohen, the issues of equality and community appeared crucial: to these I turn, respectively, in the following sections.

\section{Distributive Justice}

In the sixth chapter of Market, State and Community, I had attempted to show that the distributive outcomes of a properly framed market socialist economy might be seen as individually deserved, once desert was understood in the appropriate way. I was quite explicit about how I intended to accomplish this task. No particular conception of desert would be assumed a priori. Instead an attempt would be made to discover a conception of desert that might plausibly be used for this purpose, in the process discarding conceptions that plainly could not justify market outcomes, no matter how the market was framed. I saw this approach as analogous in certain respects to the Rawlsian procedure of reaching a reflective equilibrium. In his paper, Cohen cites the passage where I suggest how we might go about showing that a market economy can meet standards of distributive justice:

One method, at first sight the best, would be to specify our conception of justice first, and then see whether a market economy, suitably framed, could hope to instantiate it. I prefer to adopt a more oblique strategy, in which the conception of justice and the character of the market are adjusted to one another, as it were, until eventually they rest in equilibrium. This may sound like cooking the books. $^{25}$

Cohen warmly endorsed the sentiment expressed in the last sentence! He thought that it revealed only too clearly adaptive preference formation at work: we take it for granted that we are going to have a market economy, for feasibility reasons, and then

\footnotetext{
${ }^{25}$ Miller, Market, State, and Community, p. 156.
} 
we cast around for a way of showing that it is distributively just. This was not my position, but in retrospect the passage lends itself to misinterpretation. My actual view was that the general reasons for advocating a market economy were normative ones, having to do with welfare and individual freedom, but it was necessary also to show that such an economy could produce outcomes that were distributively fair, or at least came close enough to meeting that requirement. If this could not be shown, we would have strong, possibly decisive, reasons to reject the market altogether. My concern, however, was that the market might be rejected prematurely as a result of applying inappropriate standards of distributive justice - hence the analogy with the Rawlsian method of reflective equilibrium. ${ }^{26}$

I assumed that the relevant standard must be a principle of desert. Cohen challenged this, citing the centrality of the principle of need to the socialist tradition. Markets clearly do not and cannot distribute resources to people on the basis of need: the best they can do is to create sufficient resources that all needs can be satisfied, but it requires non-market institutions to bring about the distributive outcome that the principle requires. Supposing such (welfare-state-like) institutions can be created to operate alongside the market, is it a defect of the market that it does not assign resources directly on the basis of need? This, it seems to me, would be a harsh verdict. It leaves no room for a division of responsibility. It would mean that any system in which the producer of resources - the farmer who grows food, for example - does not directly ensure that the resources she produces are allocated according to need is ipso facto unjust. The correct conclusion is surely to say that a market economy that was not accompanied by non-market institutions that distributed (some of) the resources it creates on the basis of need would be unjust. But the market socialist model under discussion was clearly one in which the market sector was to be counterbalanced by an extensive welfare state.

${ }^{26}$ Cohen pointed out, correctly, that the analogy was far from exact. Rawls looks for an equilibrium between our intuitive judgements and the principles of justice that we are willing to endorse following reflection. Institutions do not enter the picture until later. My aim was to take different institutional arrangements on the one side, and principles of justice on the other, and to see how far it was possible to bring them into alignment. 
A more interesting question, perhaps, is whether the socialist tradition makes any room for a desert-based conception of distributive justice. The position that Cohen adopts in his paper is not hostile to the idea of desert as such, though it remains questionable, as we shall see later, whether the kind of desert he is willing to embrace could form part of social justice. On the other hand, he was more than happy to cite old socialist songs that expressed what it is natural to understand as a collective claim of desert - songs that assert that because we, the workers, have created the means of production with our labour, it is wrong that we are now deprived of their fruits. ${ }^{27}$. This claim - sometimes expressed in the form of the worker's right to the whole product of his labour - has clearly played a central role in the socialist critique of capitalism. It would be odd, therefore, to say that socialism has no time for desert at all; it would be better to say that socialists recognize both desert and need as grounds of distributive justice, with need, perhaps, taking lexical priority.

The crucial question then becomes what desert basis is relevant when the justice of markets is being assessed. I began from the assumption that desert bases were in general plural - it was that thought that lay behind my suggestion that we might try to find a principle that was a suitable justificatory basis for a market economy. Cohen at one point appears to endorse this pluralism, citing George Sher's book ${ }^{28}$ and describing desert as 'a messy complex thing' (p. 10), but the general thrust of his critique relies on taking effort as the relevant basis. From that starting point, it is not difficult to show that no market economy - except perhaps a modified version of the Carens model - can come even close to rewarding individuals in line with their deserts. In contrast, my argument was that people in market economies deserved to be rewarded on the basis of the value of their productive contributions, using market prices as a measure of value. I freely conceded that such contribution depended not

\footnotetext{
${ }^{27}$ For example:
}

'It is we who ploughed the prairies, built the cities where they trade, Dug the mines and built the workshops, endless miles of railroad laid, Now we stand outcast and starving, 'mid the wonders we have made....' (cited in Cohen, If You're an Egalitarian, p. 105).

This could be read as a claim of collective entitlement rather than desert; yet a desert reading seems to me natural in virtue of the kinds of activities that are highlighted. It is hard, skilled work ploughing prairies, digging mines and laying railroad track.

${ }^{28}$ G. Sher, Desert (Princeton, N.J.: Princeton University Press, 1987). 
only on effort but also on native ability, but I cited Nozick and others to the effect that it was not essential to something's being a desert base that one should reiteratively have deserved that something itself. Moreover although desert required personal responsibility - to deserve $\mathrm{X}$ on the basis of some action A, it was necessary that one be responsible for performing $\mathrm{A}$ - it did not follow that one also had to be responsible for everything that made it possible to perform A. ${ }^{29}$

Here, then, we appeared to have reached an impasse: Cohen thought that (genuine) desert depended solely on effort expended, whereas I thought that, so long as responsibility was present, desert could also reflect the outcome that was achieved, even if this depended on unequally distributed talent. This disagreement was crystallized in disagreement over an example I had introduced in which two brothers, one more naturally agile than the other, both try to rescue a neighbour's cat from a tree. My view was that the brother who actually rescues the cat deserves more gratitude even if his success is due to his greater agility, whereas Cohen was firmly of the opinion that if the two brothers had tried equally hard, they deserved equal thanks, and indeed that if the maladroit brother had spent longer trying unsuccessfully to bring off the rescue than the agile one, he would deserve more thanks:

I would also say the following, in the right sort of case 'I am more grateful to you, since you spent an hour on it, even if unsuccessfully, while he pulled it off in five minutes'. The intelligible sentiment expressed in that remark is one which the market systematically dishonours (p. 21)

The natural response to this is that it may be no bad thing if the market systematically dishonours cases of what we might call heroic ineptitude. Shouldn't the clumsy brother have realised, ten minutes into the rescue attempt, that he wasn't going to make it and then have summoned the agile one? The point is that effort may only be deserving of reward if it is effort that is intelligently deployed; and this will depend on what abilities the person in question has. Thus ability is going to influence desert

\footnotetext{
${ }^{29}$ See Miller, Market, State, and Community, pp. 167-8. There I argued somewhat tentatively for a position that I later defended more robustly in Principles of Social Justice (Cambridge, Mass.: Harvard University Press, 1999), ch. 7, esp. pp. 146-9.
} 
indirectly even if one thinks that effort, and only effort, is the direct basis of desert. If I have the relevant talent and you do not, then by expending effort in a particular direction I can become deserving of some kind of reward while you cannot.

This still leaves it an open question whether what counts is (intelligently directed) effort, or the actual result that is produced. The market, clearly, rewards people by results, and so it is vulnerable to the charge that where contingent circumstances influence the outcome, two people who are equally deserving may receive unequal rewards. So, to modify the cat-up-the-tree case, suppose now that we have two equally agile brothers, and that there are two possible routes up the tree that lead in the direction of the stranded cat, but it is not clear in advance which route is easier to climb. Does the brother who chooses the quicker route and therefore actually rescues the cat deserve more gratitude? The market analogue would be, say, two people opening cafés in different locations in the same town, where it is not possible to predict which location will prove more popular. I think that in such cases, intuition pulls us in opposite directions, as indeed John Stuart Mill argued in a well-known passage. ${ }^{30}$ On the one side we want to say that, given the way in which it has been produced, through skill and effort, it is the actual result - the rescued cat, the happy consumers of coffee and croissants - that forms the basis of desert. On the other side, it may seem unjust that the bad luck of making a poorer choice, in circumstances where it could not be known which choice was better, should be allowed to influence what is due to someone by way of reward. One way out here might be to distinguish different kinds of desert. The complaint about the market would then be that it rewards people on too narrow a basis. What it 'systematically dishonours' are the efforts of people that might have led to valuable results had circumstances been different. ${ }^{31}$ At least in the modified two-brothers case, the unsuccessful brother surely does deserve to be thanked for trying. ${ }^{32}$

\section{${ }^{30}$ J.S. Mill, Utilitarianism in Utilitarianism; On Liberty; Considerations on} Representative Government, ed. H.B. Acton (London: Dent, 1972), p. 54. Mill is there discussing how income should be distributed in a co-operative enterprise - on the basis of effort alone, or on the basis of (talent-dependent) contribution?

${ }^{31}$ It also, of course, fails to reward people for doing things that might have value, but not the kind of value that market prices can capture (such as helping to produce public goods). Cohen advances this criticism in places (see especially p. 13), but it is an odd one to make unless one was arguing with someone who thought that the market 
Whether Cohen might have been willing to accept such a compromise view - which acknowledges that there may at least be some justice in market rewards - is open to doubt. He argued as follows:

......I do not have to deny, what in fact I here neither deny or assert, that how much a person or group produces, measured in money terms, has no bearing on her or its desert. All that I need to claim is that other things affect it too. Consider, for example, effort. The only thing the market can register is achievement or success, of which effort is only one cause, not itself registered by the market. Desert may not be determined by effort alone, but its special claim to reward goes quite unheeded in the market. You might well think that achievement as such generates desert, meaning by 'as such’ independently of the amount of effort that went into it. But as long as you also acknowledge, as you surely must, that effort as such (independently of the resulting achievement) also generates desert, then you cannot say that market earnings are, in the relevant comparative sense,.....deserved. (p. 13)

He also appears to have stood fast on the idea that the arbitrariness of natural talent meant that any distributive outcome that reflected talent inequalities was to that extent unjust. Drawing upon Marx, he argued that the principle of reward according to contribution was a 'bourgeois principle, one which regards a person's talent "as a natural privilege"'(p. 24) and he linked it to the principle of self-ownership about which, of course, he had much to say. ${ }^{33}$ So perhaps the most that Cohen would have

should be the only social practice that responded to desert. A market socialist need not and should not deny that a just society ought to contain many different practices in which different kinds of desert are recognized.

${ }^{32}$ Might he deserve more than that - for example, if a reward has been offered for rescuing the cat, might justice demand that the reward should be split equally between the two brothers? My view here would be that we would draw this conclusion if we thought of the brothers as forming a team - say if they had reached an explicit or tacit agreement to attempt different routes as a way of maximising the chances of a successful rescue. In other circumstances - say if they are vying competitively for the attention of their attractive neighbour - the successful brother deserves the lion's share of gratitude, and probably all of the promised reward. 
been willing to grant (pace the above passage) was that effort as such could not count as a desert basis; that it had to be effort expended with a realistic hope of achieving something of value to others, and that this in turn would depend on whether the maker of effort had talents that promised some chance of success.

Cohen did, however, have a compromise of his own to propose, foreshadowed in the italicised phrase in the quotation above. Following a classic article of Joel Feinberg's ${ }^{34}$ he suggested that it was important to distinguish between comparative and noncomparative justice, and if one did this, one could then acknowledge that market rewards might be deserved in a noncomparative sense without being deserved in a comparative sense. In other words, one might think that the benefits people received through engaging in market activity were in some absolute sense appropriate or fitting, without also thinking that the inequalities that the market generated were just by virtue of some people being more deserving than others. As Cohen put it:

Take a hard-working and quite wealthy High Street merchant, say a mender of watches. We can ask, is it right, is it fitting, is it proper, that this man, who undeniably serves the public in, let us assume, a conscientiously self-applying way, should enjoy his house on the hill, his Granada, ${ }^{35}$ his regular holiday in Tenerife, and so on? It seems mean-minded to say 'no', to refuse to perceive a relationship of happy fit between his effort and achievement on the one hand and his income on the other.....the left-wing challenge to the justice of market inequality of reward is not to judgments of that non-comparative sort. The leftwing claim is not: he does not deserve that income, it is worse that he should get it rather than something less, it is an unearned boon...... It is that his desert of it, whatever it may be, does not justify his having it given what others get....what the left is challenging is a pattern of reward across persons, and to defend that by reference to desert you need to show that there is a corresponding pattern of greater or lesser desert, and that is the proposition which I find incredible. (p. 15)

\footnotetext{
33 See also Cohen, Self-Ownership, Freedom, and Equality, p. 259.

34 J. Feinberg, 'Noncomparative Justice’, Philosophical Review, 83 (1974), 297-338.

35 This was a mid-range family car produced by Ford and popular in the 1980s
} 
Cohen's diagnosis, therefore, was that I had been misled by the plausibility of noncomparative judgements of market justice - such as the judgement about the rewards earned by the watch-mender expressed in the paragraph above - into thinking that comparative judgements - such as the judgement that doctors deserved to have incomes several times higher than those of nurses - were also plausible. He was willing to allow that market rewards might be deserved in a non-comparative sense, provided I would agree that the inequalities of reward produced by any market economy, including market socialism, were undeserved and therefore unjust.

Was this a compromise that I could accept? Although familiar with the distinction between comparative and noncomparative justice, I had always been sceptical of the idea that one could make non-comparative judgements of economic desert. ${ }^{36}$ In the case of the watch mender, any judgement we might make about his economic deserts must therefore be implicitly comparative (albeit not very precise). We would think of the watchmaker as someone exercising a special skill, and also perhaps as in a small way an entrepreneur (Cohen's description suggests that he is self-employed rather than an employee). Knowing something about the occupational structure and the shape of the income distribution in 1980s Britain, we would conclude that he deserves at least a little above the median income, and that would translate into the range of relatively modest but still above-average benefits that Cohen identifies. In other words, if we are to stand by the desert judgement at all, we must be prepared to defend it as a comparative judgement. There is no absolute amount of reward that the watch-mender deserves.

So our disagreement over markets and desert remained unresolved. And it had one further aspect which, with the benefit of hindsight, can be seen to anticipate the larger methodological disagreement over how political philosophers should think about justice that later separated Cohen not just from me but from many of those influenced by John Rawls. In defending the claim that the market value of someone's product was an appropriate way of measuring the contribution they had made when estimating

\footnotetext{
${ }^{36}$ For my most sustained treatment of this question, see D. Miller, 'Comparative and Non-comparative Desert’ in S. Olsaretti (ed.), Justice and Desert (Oxford: Oxford University Press, 2003).
} 
desert, I had emphasized that it provided us with a publicly accessible measure of desert:

The point is not that a market-based criterion of value is appropriate for estimating desert because this is the practice that now prevails. It is rather that if we want desert to form the basis of a social practice - rather than being an idea that is used merely to form a series of idiosyncratic judgements - we need a non-arbitrary public standard to measure it. In this light, the attraction of a market-based criterion is very considerable. ${ }^{37}$

Cohen dissented sharply from these remarks:

In my view, desert is indeed 'an idea that is used merely to form a series of idiosyncratic judgements'...... I do not think, to use Miller's term, that we should want desert to be something other than that idea. That is what desert is, a messy complex thing, and we should not want it 'to form the basis of a social practice’. (p. 10)

What this exchange reveals is that I was treating desert as something capable of being turned into a principle of social justice - a principle, in other words that could form part of a society's political morality and be used to regulate its basic structure (in Rawls' sense). That was why it was an important to find a conception of desert that met the publicity condition. For Cohen, on the other hand, desert might be relevant to justice, but since justice was more abstractly conceived, it did not matter that a proper assessment of someone's desert would involve knowing things about their intention, motivation, and so forth which were not, and could not be, publicly accessible. In 1989 he had not yet devised his later distinction between principles of justice and rules of regulation. But it is clear that we already had very different ideas about what a principle of (social) justice should look like, and given this underlying difference we were unlikely to reach agreement on the basic question that we thought we were both addressing, namely 'could any market economy, however framed, be distributively just?'.

${ }^{37}$ Miller, Market, State, and Community, pp. 161-2. 


\section{Community}

As we saw earlier, Cohen's second main objection to market socialism was that, like other forms of market economy, it was inimical to the value of community. As he makes clear in Why Not Socialism?, this objection comes in two parts, of which only the second featured in the 1989 debate. The first part points to the corrosive effects of inequality on relationships between human beings. As he puts it, 'we cannot enjoy full community, you and I, if you make, and keep, say, ten times as much money as I do, because my life will then labor under challenges that you will never face, challenges that you could help me to cope with, but do not, because you keep your money'. ${ }^{38}$ The second part of the objection, in contrast, focuses on the motives that underlie market exchanges. These are not merely instrumental but, according to Cohen, considerably worse than that:

The immediate motive to productive activity in a market society is typically some mixture of greed and fear, in proportions that vary with the details of a person's market position and personal character. In greed, other people are seen as possible sources of enrichment, and in fear they are seen as threats. These are horrible ways of seeing other people, however much we have become habituated and inured to them, as a result of centuries of capitalist development. $^{39}$

Cohen went on to contrast this with people's motives under (genuine) socialism, where people would produce in order to serve one another's needs, although in the expectation that those others would in turn reciprocate the service provided.

My commitment to socialist community does not require me to be a sucker who serves you regardless of whether (if you are able to do so) you are going to serve me, but I nevertheless find value in both parts of the conjunction - I serve

\footnotetext{
${ }^{38}$ Cohen, Why not Socialism?, p. 35.

${ }^{39}$ Cohen, Self-Ownership, Freedom, and Equality, p. 262 (footnote omitted). Compare Cohen, Why not Socialism?, pp. 39-41, where some nuance is introduced but the basic claim remains unchanged.
} 
you and you serve me - and in that conjunction itself: I do not regard the first part - I serve you - as simply a means to my real end, which is that you serve me. ${ }^{40}$

My focus here will be on the second of these objections, partly because it seems to have been the one that carried most weight in Cohen's mind, and partly because the first raises difficult empirical questions a) about how large we might expect income inequalities to be under a market socialist regime, and b) about the impact that we might expect income inequalities of any given size to have on social relations generally, taking into account other features that a particular society might display. ${ }^{41}$

My own view arose from a long-standing interest in what we might call 'the sociology of the commune' - the circumstances under which people had shown themselves able to sustain, on a small scale, social relations that approximated to the Marxian ideal of communism. This led me to distinguish, in Market, State and Community, ch. 8, between the ideal of socialist community found in Marx and the position I called 'Romantic anti-capitalism' which saw capitalism simply as the negation of all genuine human relationships. Marx, I claimed, had taken a different view. He has recognized the stifling effects of primitive forms of communism, in which people had been 'engulfed' by the social roles into which they were placed. ${ }^{42}$ By freeing people from such pre-ordained roles and exposing them to the contingencies of the marketplace, capitalism had created individuals who were expected to move between different occupations, admittedly under the compulsion of economic necessity. Modern industry, he argued, requires 'the fully developed individual, fit for a variety of labours, ready to face any change of production, and to whom the different social

${ }^{40}$ Cohen, Why not Socialism?, p. 43.

${ }^{41}$ I tried to answer these questions in 'Equality and Market Socialism' in P. Bardhan and J. Roemer (eds.), Market Socialism: The Current Debate (New York: Oxford University Press, 1993) and in 'Complex Equality' in D. Miller and M. Walzer (eds.), Pluralism, Justice and Equality (Oxford: Oxford University Press, 1995).

${ }^{42}$ In developing this argument, I relied considerably on an early article of Cohen's, 'Marx's Dialectic of Labour', Philosophy and Public Affairs, 3 (1973-4), 235-61, so the issue itself was familiar to him. 
functions he performs, are but so many modes of giving free scope to his own natural and acquired powers'. ${ }^{43}$

Since for Marx, and presumably therefore for Cohen, such individuality was a positive achievement that ought to be preserved, indeed enhanced, under socialism, the question arose whether this would be possible under a non-market version of that ideal. Was there not a danger that people might once more become engulfed in particular occupations? Admittedly Marx, in a famous passage from The German Ideology had spoken of a person in the society of the future being able to 'hunt in the morning, fish in the afternoon, breed cattle in the evening, criticize after dinner, just as I like, without ever becoming a hunter, a fisherman, a herdsman or a critic' ${ }^{44}$ But this immediately invites the question: what if I turn out to be very good at fishing, but lousy at hunting and breeding cattle? Even if I come under no external pressure to confine myself to the river bank, won’t my sense of social duty impel me to become a specialist fisherman? Cohen, it should be noted, explicitly rejected the idea that socialism must await the coming of (complete) abundance. He called this Marx's 'technological fix', and dismissed it on the grounds that it neglected green concerns about the finite nature of the earth's resources. ${ }^{45}$ Instead, he proposed that we should think about socialism assuming 'a level of productive capacity which is too low to prevent significant conflicts of material interest from arising, but which is high enough to enable their peaceful egalitarian resolution'. ${ }^{46}$ Under such conditions, he thought, it would not be necessary to coerce people to engage in production; they would do so out of a sense of justice. But nothing further is said to explain why they would not become engulfed in the productive activity that seems to them to represent their greatest contribution to social welfare. Isn't that what well-motivated people would do, in the absence of a labour market? Since they have not moved beyond the

\footnotetext{
${ }^{43}$ Miller, Market, State, and Community, p. 212, citing K. Marx, Capital, vol. 1 (London: Glaisher, 1909), p. 494.

${ }^{44}$ K. Marx and F. Engels, The German Ideology in L. Easton and K. Guddat (eds.), Writings of the Young Marx on Philosophy and Society (Garden City, NY.: Anchor, 1967), p. 425.
}

\footnotetext{
${ }^{45}$ See Cohen, Self-Ownership, Freedom, and Equality, ch. 5.

${ }^{46}$ Cohen, Self-Ownership, Freedom, and Equality, p. 128.
} 
realm of necessity, they cannot afford to adopt the dilettantish attitude to work ('just as I like') that Marx appears to be suggesting in his description of the higher stage of communism.

In his later writing, Cohen does consider at some length the issue of self-realization in work, and how this may legitimately affect people's occupational choices: his thought it that a person may permissibly take on a less socially useful job if the more useful job she could perform would come at a heavy cost to her self-realization. ${ }^{47}$ In general this buys plausibility at the cost of indeterminacy (just how much personal selfrealization should one be willing to sacrifice in the name of making a greater social contribution?). However this concession does not directly target my concern about the possible effects of non-market methods of job allocation on individual freedom. The concern is that once they have made their initial occupational choices, people are sheltered from the disruptive effects of changing market conditions, which in market economies will force them periodically to reassess the role they are playing in the sphere of production. One might argue that some sheltering is desirable: markets are unforgiving of those who try to keep working at jobs for which there is no longer adequate demand. So much will depend on how far one accepts the ideal of the fully developed individual expressed in the passage from Capital cited above, with its emphasis on flexibility and performing different social functions. If one does accept it, then the worry about the scheme favoured by Cohen, in which people are given no material incentives to take one job rather than another, but are left to make their own decision having balanced likely social contribution against personal job satisfaction, is that they are under no pressure to reassess that choice over time. They are vulnerable to the 'engulfment' in a particular social role that Cohen, following Marx, had seen in his earlier work as characteristic of pre-capitalist forms of production. ${ }^{48}$

\footnotetext{
${ }^{47}$ G. A. Cohen, Rescuing Justice and Equality (Cambridge, MA: Harvard University Press, 2008), ch. 5, sect. 4.

${ }^{48}$ It might be argued that it was the preordained character of the roles that people occupied in pre-capitalist societies that produced engulfment, so that where people are free to make their initial choice of occupation, no such problem will arise, since consciousness of the possibility of choosing differently will persist. But this depends on a claim about human psychology that appears fragile, though I cannot explore the point further here.
} 
This problem is camouflaged in the camping trip example that opens Why Not Socialism? It is camouflaged, first, because the people who take the trip are, by implication, people whose individuality has been nurtured by a (capitalist) market society, and who have decided voluntarily to join forces for the purposes of the trip; second, because the trip is sufficiently short-lived that there is no real danger that the campers will fall into narrowly-defined roles on the basis of their respective abilities. ${ }^{49}$ It is not clear whether Cohen would have recognized this problem. When facing a critic who asks 'Is the camping trip a special case?' he focuses on the question whether the motivations that sustain it could be reproduced on a society-wide level, but not on the question whether it might rely upon individuality-promoting features in the background that would not be present in a society organized entirely along communitarian lines (there is no evidence, for example, that he had studied the factors that have tended to produce a fixed division of labour in the Israeli kibbutzim, despite the fact that their founding ideology explicitly endorses the rotation of tasks). ${ }^{50}$

So my first challenge to Cohen on the question of community is to ask whether the form of community that a non-market socialism would require might not be destructive of individuality - or to turn the challenge around, how the liberating achievements of a market economy, when compared to earlier forms of human society, would be preserved in a future, post-market order. But this would still leave unanswered his remarks about the alienating effects of market motivation. What should one say about these?

First, it seems a great exaggeration to say that people interacting in market settings are characteristically motivated by greed and fear, even though these motives may undoubtedly sometimes be present. It seems to rule out the honest tradesman or

\footnotetext{
${ }^{49}$ These special features of the camping trip are highlighted in Miriam Ronzoni's powerful critique of Cohen: see M. Ronzoni, 'Life is not a camping trip - on the desirability of Cohenite socialism', Politics, Philosophy and Economics, 11 (2012), 171-85.

${ }^{50}$ For an interesting discussion of the forces that have more recently propelled many kibbutzim in the direction of a form of market socialism, see A. de Shalit, 'David Miller's Theory of Market Socialism and the Recent Reforms in Kibbutzim', Political Studies, 40 (1992), 116-23.
} 
shopkeeper who, though no doubt happy to be paid for his services, is also happy that he is able to provide his customers with goods that they need or want. Furthermore, Cohen appears to run two different cases together when he says that 'one's oppositenumber marketeers are predominantly seen as possible sources of enrichment, and as threats to one's success'. ${ }^{51}$ There is, on the one hand, the customer, who may be seen as only a source of enrichment (though one might question whether success in the market will actually be achieved by so regarding her); there is also, on the other hand, the rival producer or tradesman, who may be seen as cutting into one's market share or in the worst case as driving one out of business - hence the threat. The customer, then, is not a threat, and the business rival is not, except indirectly through his elimination, a source of enrichment. Moreover it is worth noticing that people offering goods and services in the market are not typically engaged in zero-sum competition; that is, they may be satisfied so long as each can maintain an adequate market share. The ambition to own, let's say, the biggest grocery store or the most popular restaurant in town may exist, but it is an extra-market motivation. In this respect, market competition is unlike, for instance, several junior professors competing for a prestigious Chair that only one of them can occupy - they are really rivals in a way that the grocers or restaurant owners are not.

Hyperbole stripped away, it remains the case that people's motivation when they engage in markets is primarily instrumental, and therefore, on the face of it, less noble than the motivation of someone who aims directly to meet another's needs. But we also know that markets have considerable virtues, not least - as Cohen freely admitted - that they are often very effective as a means of directing resources and labour to their most productive uses. So couldn't someone engage in market activity instrumentally while fully conscious that she was participating in a practice whose value lay in its overall contribution to social welfare - she may be thinking less about the benefits that might accrue directly to her partners in exchange and more about the advantages that the system confers on a much wider constituency? Consider, by way of analogy, a group of committed egalitarians who have to share a heterogeneous set of resources among themselves. ${ }^{52}$ Having, fortunately, read Ronald Dworkin's

\footnotetext{
${ }^{51}$ Cohen, Why not Socialism?, p. 40.
} 
celebrated articles, ${ }^{53}$ they know that what they must do is to bring in an outside auctioneer, find some clamshells, and then bid competitively for the items that the auctioneer offers in turn. It will be no good at all if John underbids for the pruning knife that he would like to own because he can see that Jane would like it too and he is altruistically concerned for her welfare - such behaviour would subvert the whole point of the auction, which is to assign goods in such a way that, finally, nobody envies anyone else's bundle. So when John outbids Jane, this is not seen as undermining their communitarian relationship; Jane may be frustrated at not getting the pruning knife, but because she understands the wider aim of the auction, she does not resent John's behaviour. Community is expressed in their joint commitment to share resources equally via the device of the auction.

I do not mean to suggest that it is sufficient for a community to exist that its prospective members, despite interacting directly with one another in an instrumental manner, are able to grasp that their practices contribute to common goals. This again brings us back to the fact that market socialism, as a political project, involves more than just the market itself. So the issue is not whether markets, alone, can create a sense of community among participants, but whether they are so inimical to communal relationships that we are faced with the fairly stark choice between markets and socialism with which Cohen presents us. My argument, in short, is that market socialism, in tandem with non-market institutions, could be communitarian enough, and that forms of socialism that promised thicker forms of community might threaten freedom, understood as the opportunity for each person to develop and express their latent powers, not least in occupational choice.

\section{Conclusion}

52 In Market, State, and Community, p. 221, I had used the example of two friends playing tennis, where the game is most enjoyable if each struggles as hard as he can to win. 'On the surface the relationship is competitive....underneath the game is a cooperative enterprise for mutual enjoyment.' I recall Cohen not being very impressed with this analogy for markets, but I cannot now remember what his reasons were.

${ }^{53}$ R. Dworkin, 'What is Equality? Part 1: Equality of Welfare', Philosophy and Public Affairs, 10 (1981), 185-246 and R. Dworkin, 'What is Equality? Part 2: Equality of Resources', Philosophy and Public Affairs, 10 (1981), 283-345, now reproduced as R. Dworkin, Sovereign Virtue (Cambridge, Mass.: Harvard University Press, 2000), chs. 1-2. 
In 1989, the debate about market socialism still had a political edge to it. The grand question was whether socialism had a future at all following the collapse of the Soviet Union; the more parochial one was whether the public philosophy of the British Labour Party should come to include a warmer embrace of markets. For reasons that are too obvious to need spelling out, this political edge has since disappeared. So at a substantive level, the debate between market socialism and Cohenite socialism is now perhaps chiefly interesting for the light it throws on wider questions of political philosophy, some of them raised above, such as the respective roles played by equality and desert in the theory of distributive justice, and the compatibility or incompatibility of the ideas of freedom and community. These questions are worth pursuing for their own sake even if the particular models of socialism in which they had become embedded have lost their political relevance.

There was, however, another question that I now believe lay behind the original debate (though I was not aware of it at the time), one concerning the nature and purpose of political philosophy itself. In his essay 'The Future of a Disillusion', Cohen had outlined two possible ways in which people might respond when faced with the practical collapse of their political ideals. One was adaptive preference formation, already discussed. The other was what he called the 'Vanity of Vanities' response, which says:

....genuine socialism is impossible, or virtually impossible to achieve. It is overwhelmingly likely that the best we shall ever get is some kind of capitalism, and it is for others to find the strength to fight for a better capitalism. Here the old ideal remains bright, but the will collapses, and, integral to its collapse, both helping to induce it and feeding on it, is a pessimistic judgement of possibility that spreads its gloom across perception of the whole feasible set, so that the person says: what is really good is not to be had, and there is nothing else that is good enough for me to devote myself to. ${ }^{54}$

\footnotetext{
${ }^{54}$ Cohen, Self-Ownership, Freedom, and Equality, p. 254.
} 
In the unpublished paper he compares this attitude to that of 'Hegel's beautiful soul, which withdraws from the crock of horse manure world which frustrates high minded designs. It withdraws towards contemplation of its own impotent purity.' (p. 3)

Now Cohen admitted that he felt tempted by the 'Vanity of Vanities' response, but cautioned against it, saying that in politics it 'almost always betokens irresponsible self-indulgence'. Yet in the longer term, as I see it, he succumbed to something like this position. ${ }^{55}$ If we look again at Why Not Socialism?, what we are being offered is in no sense a political proposal, but in effect an ethical critique of capitalism, and of markets more generally. As Alastair MacIntyre has remarked in his review, this is 'a very odd book for someone strongly influenced by Marx to have written', and that is because the ideal it presents is wholly disconnected from any practical concerns that might motivate people to engage in political action leading towards it. ${ }^{56}$ Cohen, it is true, does concede in that book that market socialism remains 'an eminently worthwhile project from a socialist point of view', but his praise of it is so lukewarm, and the accompanying criticisms so damning, that is hard to imagine anyone reading Why Not Socialism? and resolving to go out and fight for market socialism.

The wider question this raises is what place there is in political philosophy for ethical critique that deliberately refuses to engage with questions of motivation and feasibility. Is it an essential precursor to applied political theory, or a misguided enterprise that deprives the subject of any practical relevance? Provoked in part by the defence of 'fact-free' political philosophy presented by Cohen himself in Rescuing Justice and Equality, this has become a central point of discussion in the field. Seen from this perspective, some of the key issues raised in the debate about market socialism - such as whether principles of social justice must be of a kind that can be applied directly to law and public policy - anticipate the contemporary debate between 'realists' and 'idealists' over the nature of political philosophy itself. So to

\footnotetext{
${ }^{55}$ In another essay, 'A Tale of Two Cities; Or, Political Philosophy as Lamentation', in D. Miller, Justice for Earthlings: Essays in Political Philosophy (Cambridge: Cambridge University Press, 2013), I have described Cohen's later political philosophy as 'neo-Augustinian' in character.
}

${ }^{56}$ A. MacIntyre, Review of G.A. Cohen, Why Not Socialism?, Ethics, 120 (2010), 391-5. 
continue the debate about socialism today, one would need to grapple not only with the far-reaching changes in the world economy that have occurred since 1989, but also with second-order questions of method in political philosophy that were present, albeit in disguised form, in the original dispute. 